\title{
見学記
}

\section{東京電力（株）技術開発研究所・電気の史料館 見学記}

東京電力（株）技術開発研究所、電力貯蔵ソリュ ーショングループ 中島 達人 様のお世話により、 2003 (平成15) 年 8 月 5 日 (火) 13:00 17:00、 東京電力 (株) 技術開発研究所および電気の史料館 （神奈川県横浜市鶴見区江ヶ崎町 4-1）の見学会を 実施いたしました。見学に当たっては、

$$
\begin{aligned}
& 13: 00 \sim 15: 00 \ldots . . . \text { 技術開発研究所 } \\
& 15: 00 \sim 17: 00 \ldots . . . \text { 電気の史料館 }
\end{aligned}
$$

というスケジュールで、見学させていただきました。

まず、研究所屋上にて太陽光電池パネルの長期運 転試験について説明を受けました。素子の違い、設 置条件の違いなどについての知見を積み重ねている とのことでした。次に見学した固体高分子形燃料電 池は現在、電気自動車用として脚光を浴びています が、将来的には家庭などにも設置し、電源の分散化 を図るのにも適していると考えられるそうです。 NAS (ナトリウムー硫黄) 電池は比較的高温で運転 され、ナトリウムが危険物であるため、安全性の確 保が課題でしたが、現在は実用段階に入り、研究所 でも運転実績が積み重ねられていました。様々な施 設での導入に向けて、活発な営業活動が行われてい るそうです。

電気の史料館においては、明治以来の日本の電力 供給体制の変遷をみることができ、エジソンに始ま る海外での電力関係の機器も展示されていて、電気 の歴史を担った実際の装置が展示されていました。 また、火力発電用のタービンと発電機のカットモデ ル (これは実際に使われていた発電ユニットをカッ トしたものだそうです）が置かれていて、通常の発 電所見学では見ることができない、発電ユニットの 内部構造を間近に見ることができました。
「電気の史料館」は一般の見学が可能 (有料) で すので、是非、訪問されることをお薦めいたします。 (文責 : 木村 紀之・大阪工業大学)

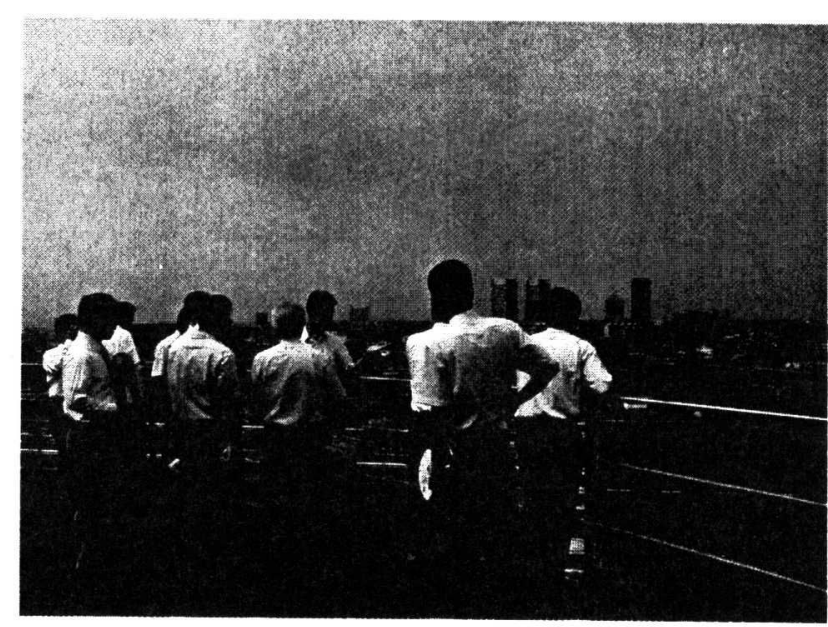

写真 1 研究所屋上にて太陽光電池パネルの 研究について説明を聞く

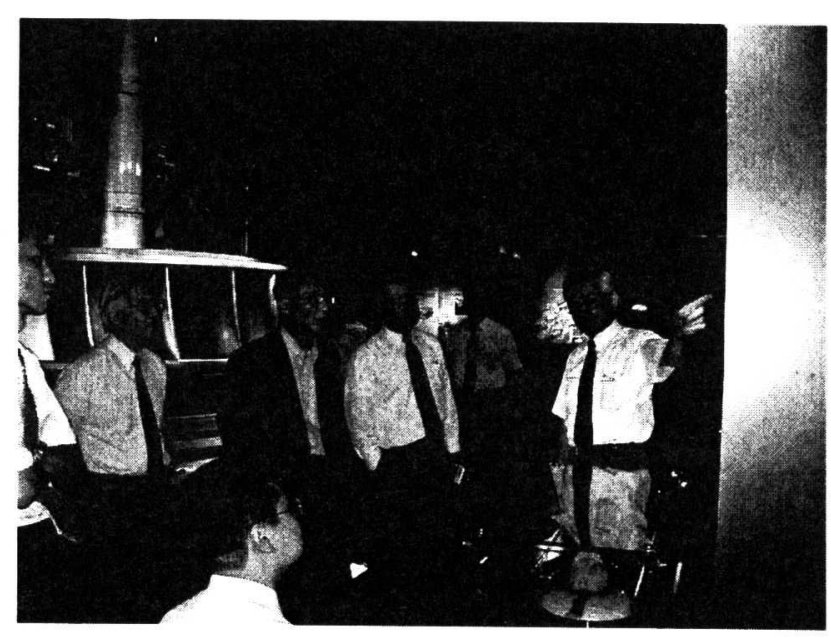

写真 2 史料館にて実物の水車を背に、 水力発電の説明を聞く 